\title{
The Slope Dynamic of Cilacap Backshore During Transition Season
}

\author{
Florencius EkoDwi Haryono ${ }^{1 *}$, Lazuardy Nalendra ${ }^{1}$, Mukti Trenggono ${ }^{1}$, Amron Amron ${ }^{1}$, Hartoyo ${ }^{1}$ \\ ${ }^{1}$ Marine Science Department. Faculty of Fisheries and Marine Science.Jenderal Soedirman University, Purwokerto
}

\begin{abstract}
Indonesia as one oftropical and archipelago countriesis daily illuminated by the sunlight.The integration of sunlight and earth pseudo-movement cause a dry and rainy seasons. The transition from one to another seasonoccur twice a year, which isMarch-May (first transition season) and September-November (second transition season). This research aim was to analyze the foreshore slope dynamic atCilacapcoast during the transitionseason. Data of slope dynamic were collected bi-weekly from March to May 2017 at 16 sites, where the distance of each site was 2 miles. The angle of slope was measured perpendicular to the shoreline using Theodolite,i.e. at the boundary of coastal vegetation, center site and foreshore waterline at low tide. The backshoreslope at four sites were increase at the second month and at the end of the transition seasonwas decline. The changes of foreshore slope at other siteswere decrease. The monthly dynamic of foreshore slope in the transitionseason underwent a narrow of change and different condition. The highest and lowest slope of the coast occurred on April (8\%) and May (5.2\%) consecutively. The transition season wasmostly influenced by the changes of wind pattern thatwouldaffect the ocean wave and the impacttobackshore slope was vary. The backshore slope changes were shown that more slopingat the end of the season. The transition season had an impact onbackshore slope and statistically, the monthly changes of coast slope weresignificant difference $\left[\mathrm{p}_{(0.05)}\right]$.
\end{abstract}

\section{Introduction}

The position of Indonesia lies around the equator always gets sunshine every day and included as a tropical climate country. The influence of the condition has cause two seasons, the rainy season and the dry season. The transition from one to another season occurs twice a year, which areMarch-May (first transition season) and SeptemberNovember (second transition season). However, inter annual fluctuations are not only locally but also remotely controlled by regional- and global-scale climate variability modes [10]. The fundamental difference between two seasons can be impact to winddirection. Wind direction in monsoon comes from the Northwest (West wind) and in the dry season is dominated by the Southeast wind. Wind direction during the transition season is unpredictable, at the end of the first transition season the wind direction turns to the Southeast wind. Unpredictable wind direction and wind power have affected to direction and force of wave. The meeting area between land and sea is know as a beach.

The continuous influence of wind, waves and tides has led to coastal dynamics [10]. Oceanic current and wave affect the changes of coastal morphology. The tide as a long wave with wavelength can reach one half of the equator (Kalay, 2008). Those condition has impact to influencethe process of sediment dispersal. The key role in process of sediment dispersal is influence of tidal plays [1]. Wind, water, ice, and gravity are the energies which capable of transporting and sinking the sediment [6]. Furthermore, the highly number of erosion along the coast causingthe vulnerability of coastal [4].

The process of coastal dynamic has displayed along shore that impact to the specification of coastal morphology. Rivers support the main source of coastal material and coastal plains supply. Theestuarine system effectively traps the particles originating from the watershed and dominated by fluvial sources, particles of a more oceanic provenance [2]. On the other side, sea-level rise has played a fundamental role in the development of the low-lying coastal environment [14]. The difference betweenthe response of natural and human interventions to coastal as backdrop of researched of coastal dynamic. The importance is evaluated to provide direction for future research that would help to form a way out of the present situation and sustainable planning for this coastal. The objective of the

Corresponding author:marine_2807@yahoo.com 
study was to analyze the dynamics of coastal backshore in the March-May as the transition season in the Southern coast of Cilacapdistrict, Central Java

\section{Material and method}

The data collection is to measure the slope of the backshore of Cilacap district. Data of backshore slope was collected bi-weekly from March to May 2017 at 16 sites, and the distance of each site was 2 miles. The angle of slope was measured perpendicular to the shoreline using Theodolite. The slope backshore data of each location is taken on three points i.e. on each site at the boundary of coastal vegetation, center site and foreshore waterline at low tide.Furthermore, data were analyzed descriptive and statistical $\mathrm{p}$ $(0.05)$ as well as coastal slope mapping.

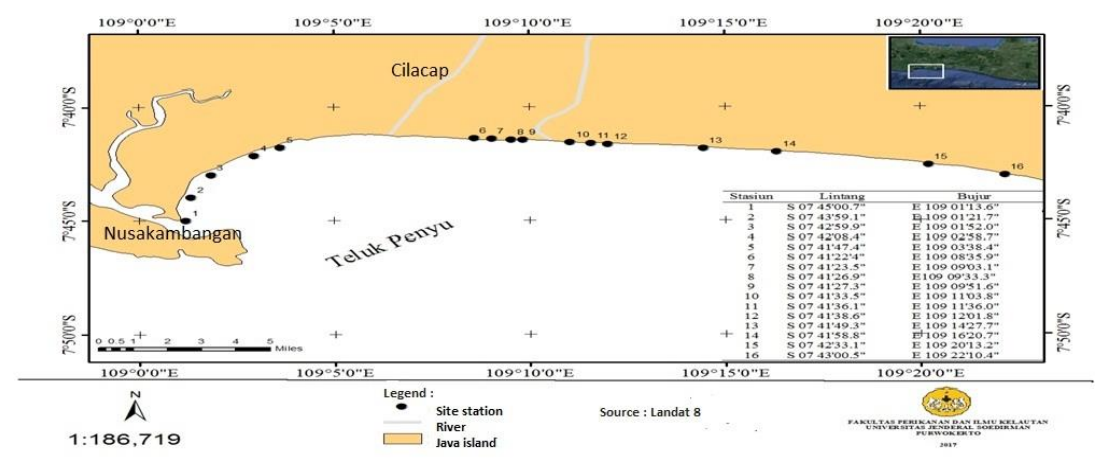

Fig. 1. Sites of study

\section{Result and discussion}

The Southern Coast of Java Islandis an integral part of the permanent influence of the tropical season. The seasonis experienced the influence of seasonal winds that remain in the rainy and dry seasons.These conditions affect the oceanographic parameters of the Indonesian oceans, which further affects to the coastal of Cilacap. The blow of seasonal winds fix and stronger influence to the ocean wave. The influence of winds at transitional season is more dynamic. The influence can be impact to the changes of wind direction. These conditions indirectly affect the dynamics of Cilacapcoast morphology. Cilacap beach is a gulfwaters that stretches from East to West [Fig. 1]. Coastal conditions in the eastern part are open water and directly affected oceanographic conditions of Indonesian ocean. The Nusakambangan Island protects the Western coast.The direction and strength of the wind blow vary during the transition season. Those conditionsaffect the fixed waves from the Indonesian oceans, wind-driven currents and waves.Additionally, the blow of wind affectsthe constant influence of currents and tidal waves. All these effects take place in an integrated manner and the result cause to coastal morphological changes. The slope of the backshorethat part of coastal morphological parameters undergoes change during the transition season.

The dynamics of the slope of the coastal plains was obtained to change during the transitional season with the changes was synchronizedwiththe influence of direction and wind energy. (Fig. 1). 
Foreshore slope
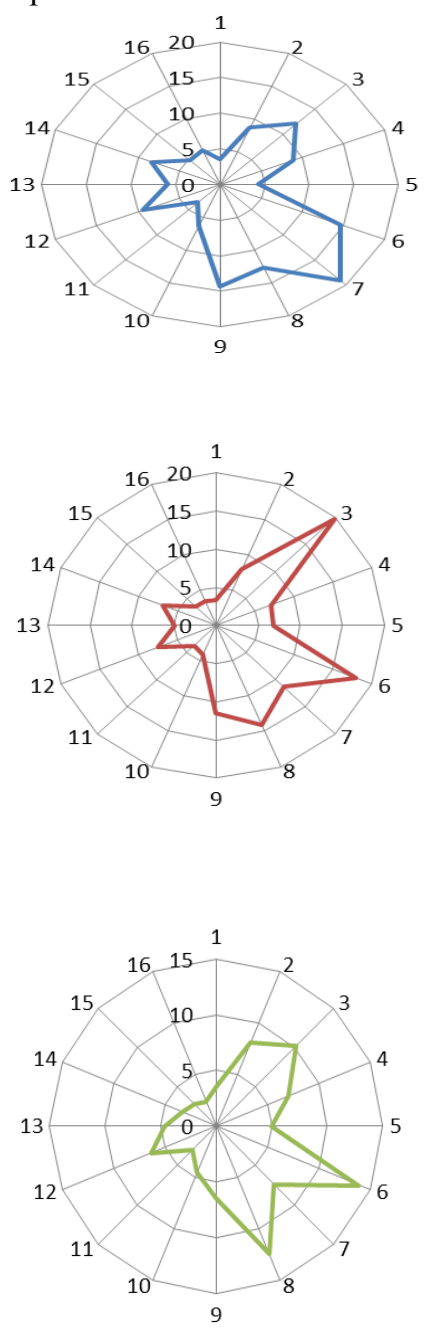

Wind direction

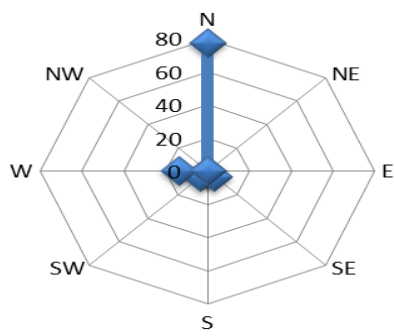

(a) March

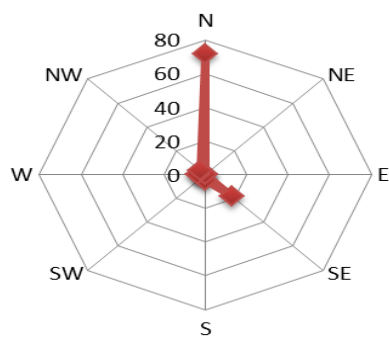

(b) April

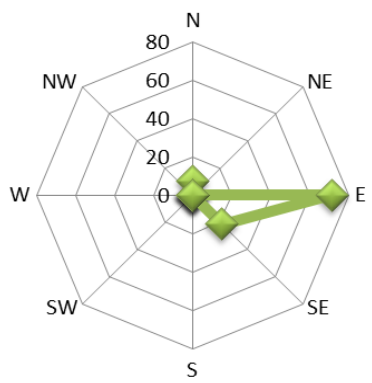

Fig. 2. Degree of backshore slope dynamics of Cilacap coast at each station

The change of backshore slope in March to April was highly increasedon 5 stations, namely the station 3, 6, 7, 8 and 9. Station 3 was sheltered beach with the existence of Nusakambanganisland from the direct influence of oceanographic of Indonesian ocean. Location of the station was Eastern of the Ocean Fishery Port of Cilacap (PPSC). The station 6, 7, 8and 9on the Southern of Serayu riverestuary which is open beach from the oceanography of Indonesian ocean. The backshore slope on stations 3,6 and 8 were increase and the slope on station 7 and 9 were decrease. The backshore slope on 5 stations was decrease generally. The shrinking slope of the coastal plains indicates that the coastal plain is getting sloping.

Station 3 was obtained as greatest increment of tilt among other stations. The station condition was closely related to the construction of ship channel that built into the sea. The construction has caused a deflection of tidal currents, flowing along the coast from East to West and turn down the construction of the path to the South. At the location, accumulation the style of tidal period causesthe sediment to be moved to the sea. The final result was increaseto the backshore slope. Position of station 6 and 8 wasin the two of river estuaries. Impact of those locationwas increase the backshore slope. The condition is related to the direct influence of the impact of Indonesian ocean, shape of river estuary and tide and low tides. The transition season conditions still cause rain which 
sedimentation on the coast, Based on the increasing slope showing the effect of the season on moving sediment according to the pattern of tidal current and low tide to the nearby station. Station 5 and 7 receive sediment and the smaller the angle of tilt.

Direction of wind in March is dominated fromSouth and blow weak West wind. April is dominated from Southand began to blow weak of Southeast wind. Wind-induced wave as wind driven current patterns. The current was moving sediments to coast and the impact causing the sediment become accumulate on shore. The upper layerof water is influenced by wind conditions [11]. The influence of the sediment displacement to beach gets sediment delivery and the impact of that to the angle of the backshore slope become smaller.

The backshore slope from April to May was decrease on each station, except on station 2, 4 and 5. The decrease inclination as a result of the weakening of South winds force that turns anEast and Eastern winds at the end of the transition season. The change of wind direction affectsdirection and wave energy. The location of station 2, 4 and 5 are located near toseaward coastal buildings, namely station 2 located at breakwater, station 4 and 5 at Western and Eastern Electric Power. Seaward jetting have affect the tidal currents. Based on the structure of the electric power causechange of tidal current and receding current direction. The direction of the tidal stream had previously been down the coast turned into a sea. In these region the energy of the current moves the coastal sediments to seaward and causes the increasing backshore slope. Monthly dynamic of foreshore slope in each site (Figure 3) wasshow fluctuate.

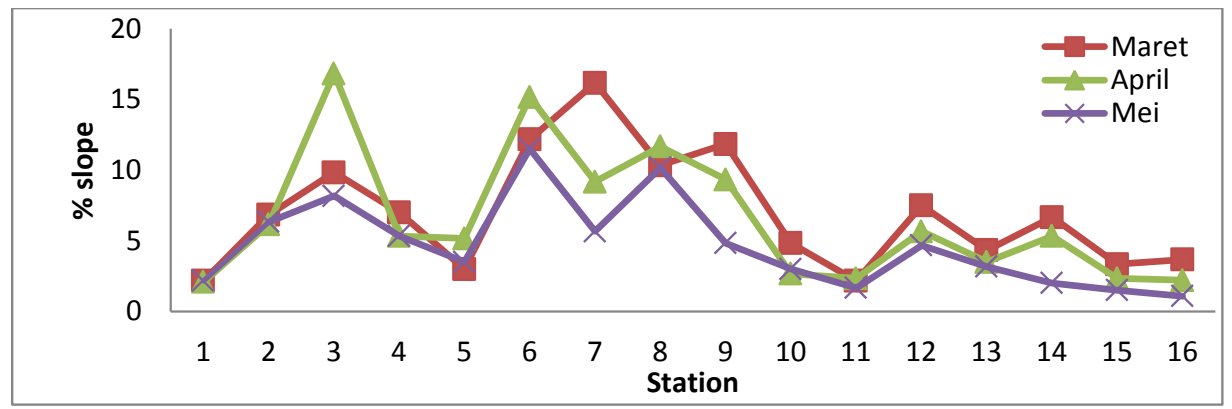

Fig. 3. Monthly backshore slope dynamics

The pattern of tidal current along the coast has moved coastal sediments on the East coast and becomes increasingly gentle at the end of the season. Wind direction of the season is dominated by the South wind at the beginning of the season and the East wind is getting stronger at the end of the season. Such conditions affect to the height of the wave, which the stronger wind causing the higher waves. The resultant style of seasonal wind of the Indonesian ocean wind and the coastal morphology of Cilacap as gulf, integration of both conditionsbecome specific impact to the backshore slope of Cilacap coastal plain, especially the movement of coastal sediment transport at the backshore.

Wind direction at the end of the transition seasonon May was dominated of East wind and wind power become stronger. The wind affects the wave height directly and the wave becomes higher. These wave energy moving toward the shore moved the sediments at sea to shore and the slope of the coastal plains became even flatter, further effects to coastal morphology [12]. Statistically of monthly backshore slope dynamic [Kruskal Wallis $\mathrm{p}<0.05]$ was obtained significant difference.

\section{Conclusion}

The dynamics of Cilacap backshore slope foreshore in transition season (March-May) was obtained greater in March to April and progressively flatter at the end of the season [May]. The seasonal winds affect to coastal slope and affect the width of the coastal structure. Based on the conditions need an attention to stakeholder to the direction of tidal currents and wind driven current that support the change of the backshore slope of the coastal plain of Cilacap. 


\section{References}

1. Akter, J., Sarker, M.H., Popescu, I. and Roelvink, D.. Journal of Coastal Research, 32(5), 1212-1226 (2016)

2. Alexander, C.R. and Windom, H.L., Journal of Coastal Research: 33, Issue 3: 548-563 (2017)

3. Anggraeni, S.K., A. Satriadi., A.D.S.P. Agus. Journal Of Oceanography. 5, No: 3, Hal: 390-397 (2016)

4. Boruff, B. J.; Emrich, C., and Cutter, S. L. Journalof Coastal Research, 21(5), 932-942 (2005)

5. Fadika, U., A. Rifai., B. Rochaddi. Journal Of Oceanography. 3, No: 3. 429-437 (2016)

6. Friedman, G. M. \& Sanders, J. E. John wiley \& Sons, Inc, 792pp (1978)

7. Kalay, D.E. Mastes Tesis.SekolahPascasarjana, Institut Pertanian Bogor. Bogor (2008)

8. Komar P. D. CRC HanbookOf Coastal Procesess and Erosion.CRC Press, Inc. Boca Raton, Florida (1983)

9. Loupatty, G. Jurnal Barekeng. Vol. 7(1):19-22 (2013)

10. Manta, G.; Barreiro, M.; Ortega, L., and Defeo, O., Journal of Coastal Research. 33, Issue 3: 531-536 (2017)

11. McPhaden, \& S. P. Hayes..J. Geosphys. Res. 96: 3331-3342 (1991)

12. Nontji, A.. PenerbitDjambatan. Jakarta (2005)

13. Scott, T., G. Masselink, P. Russell. School of Marine Science and Engineering, University of Plymouth, Drake Circus, Plymouth, United Kingdom. No. 10, p:1-20 (2011)

14. Vankoningsveld, M.; Mulder, J. P. M.; Stive, M. J. F.; Vandervalk, L. and Vanderweck, A.W. Journal of Coastal Research, 24(2),367-379 (2008) 